Article

\title{
Sea Reclamation Status of Countries around the South China Sea from 1975 to 2010
}

\author{
Junjue Zhang ${ }^{1,2,3,4}$, Fenzhen Su ${ }^{1,3, *}$ and Zhi Ding $1,2,3,4$ \\ 1 State Key Laboratory of Resources and Environmental Information System, \\ Institute of Geographic Sciences and Natural Resources Research, CAS, Beijing 100101, China; \\ zhangjj@lreis.ac.cn (J.Z.); dingzhi11@mail.ucas.ac.cn (Z.D.) \\ 2 University of Chinese Academy of Sciences, Beijing 100049, China \\ 3 Collaborative Innovation Center for the South China Sea Studies, Nanjing 210023, China \\ 4 School of Geography, Beijing Normal University, Beijing 100875, China \\ * Correspondence: sufz@lreis.ac.cn; Tel.: +86-10-6488-8956 \\ Academic Editor: Yu-Pin Lin \\ Received: 13 March 2017; Accepted: 19 May 2017; Published: 23 May 2017
}

\begin{abstract}
As a way of turning sea into land for living space for humans, the actions of sea reclamation bring about significant benefits. Nevertheless, it is also an under-recognized threat to the environment and the marine ecosystem. Based on images in two periods, sea reclamation information of countries around the South China Sea was extracted from 1975 to 2010. The spatial state and driven forces of sea reclamation are then discussed. Results show that the overall strength of sea reclamation in the South China Sea was great. New reclaimed land added up to $3264 \mathrm{~km}^{2}$. Sea reclamation for fish farming was the main reclamation type and widely distributed in the whole area, especially on the coast from the Pearl River Delta to the Red River Delta, and the coast of Ca Mau Peninsula. Sea reclamation in China and Vietnam was rather significant, which occupies $80.6 \%$ of the total reclamation area. Singapore had the highest level of sea reclamation. New reclaimed land for fish farming holds a key role in China, Vietnam, and Indonesia, while new reclaimed land for construction and docks dominated in Malaysia, Singapore, and Brunei. Areas and use-type compositions of new reclaimed land in countries varied greatly due to the differences of economic factors, policy inclination, and landscapes in the respective countries.
\end{abstract}

Keywords: sea reclamation; South China Sea; land use; landscape

\section{Introduction}

Coastal zones are the most densely populated and economically developed areas. Almost one-third of the global human population currently lives along the seaboards of East and Southeast Asia [1]. Accompanied by migration to the coastal zone, the population and economics are consistently growing. It has greatly impacted land use patterns [2-5]. Nowadays, coastal zones are facing serious problems of land shortage. With the advantages of a low cost and ease of use, sea reclamation occurs more and more frequently. To a certain extent, it meets the needs of expanding living space for humans and economic development.

As the main method of utilizing the ocean, sea reclamation is prevailing in many countries, such as Holland, Japan, and Korea [6-8]. Countries around the South China Sea also have a long history of sea reclamation. Early land reclamations in Singapore date back to the 19th century and large scale land reclamation projects have taken place since its independence in the 1960s. Land reclamation works occur in most coasts of Singapore Island and the adjacent islands, including Ubin Island, Jurong Island, and Sentosa Island [9-11]. China has continuously reclaimed coastal sea areas from the 1950s and sea reclamation has tended to be more extensive, faster, and more large-scaled, especially in the last 
two decades of 20th century. The land-use types of coastal reclaimed lands vary from agricultural land through to beach aquaculture land to construction and dock land [12-16]. Coastal reclamation works have been carried out in Malaysia since the 1950s and large-scale reclamation projects are concentrated along the coast of the Malacca Strait [17,18]. In Vietnam, Thailand, and Indonesia, large areas of mangrove forest have been filled into land for aquaculture [19-21].

Meanwhile, sea reclamation also causes severe environmental problems, such as a decline in fishery resources, sediment deposition, and wetland degradation [22]. The South China Sea is one of the primary mangrove distribution centers in the world and the mangrove area accounts for about $28 \%$ of the world's total mangrove area [23]. Additionally, the South China Sea has a favorable fishery environment and rich fishery resources. In 1998, the Asian region produced the largest amount $(72 \%)$ of whole shrimp [24]. Large-scale disordered sea reclamation works may damage the abundant resources in the region. This study obtained new reclaimed land information in the coastal zone around the South China Sea from 1975 to 2010 and analyzed the total distribution, differences, and driven forces between countries. This research is of great significance to the works of land resource planning, development and protection of coastal zones, and global environment change research.

\section{Materials and Methods}

\subsection{Study Area}

The South China Sea is located in a tropical and semi-tropical region, between the latitudes of $4^{\circ} \mathrm{S}$ and $24^{\circ} \mathrm{N}$ and between longitudes $102^{\circ} \mathrm{E}$ and $123^{\circ} \mathrm{E}$. In terms of geographical location, it is the crossroads between Asia and Oceania, connecting the Pacific and the Indian Oceans (Figure 1). As the world's third largest continental margin sea, the area of the South China Sea exceeds 3 million square kilometers. The South China mainland, Indochina, Malay peninsulas, and the Malay Archipelago surround the sea. There are nine countries around the South China Sea, including China, Vietnam, Cambodia, Thailand, Malaysia, Singapore, Indonesia, Brunei, and the Philippines.

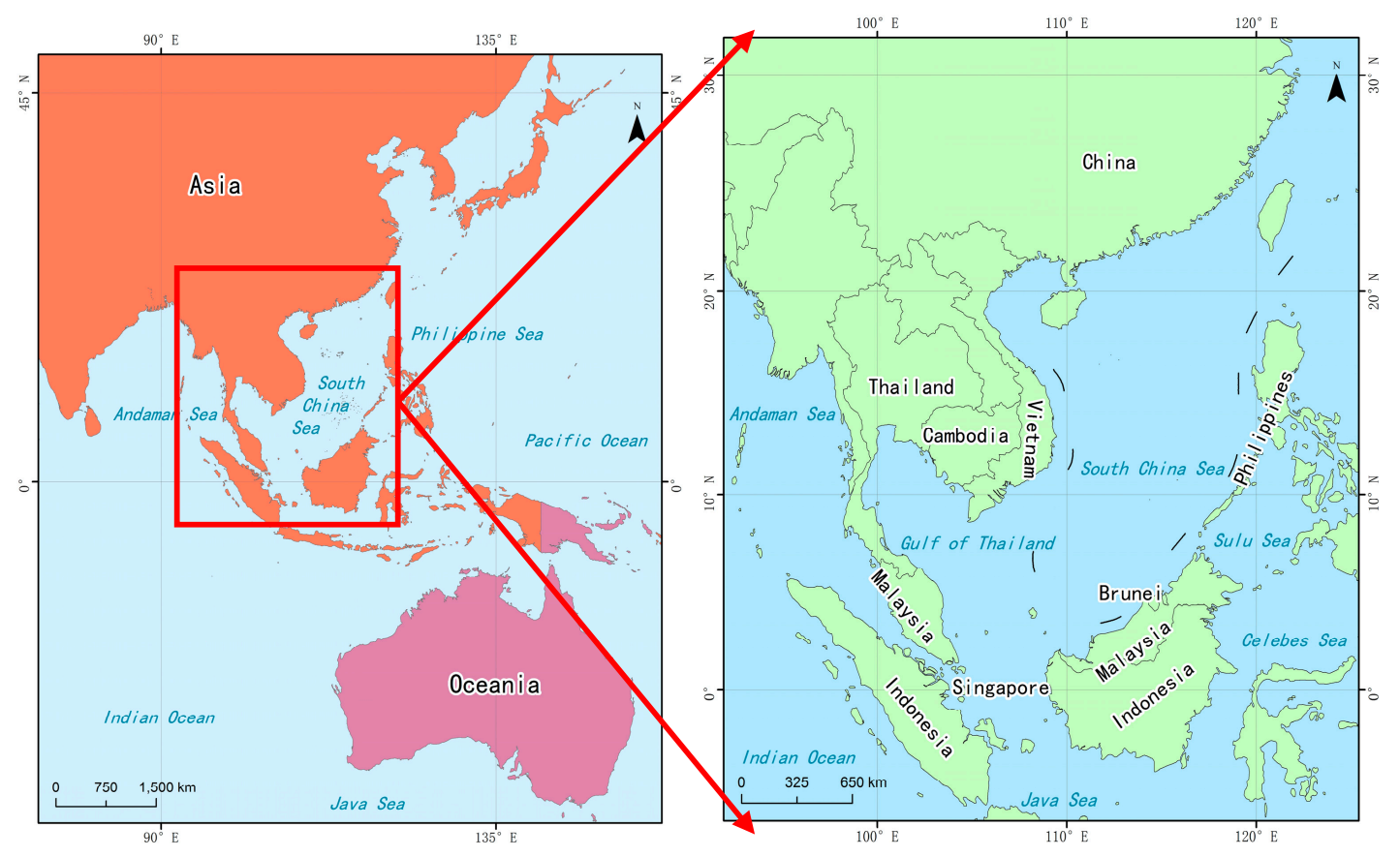

Figure 1. Cont. 


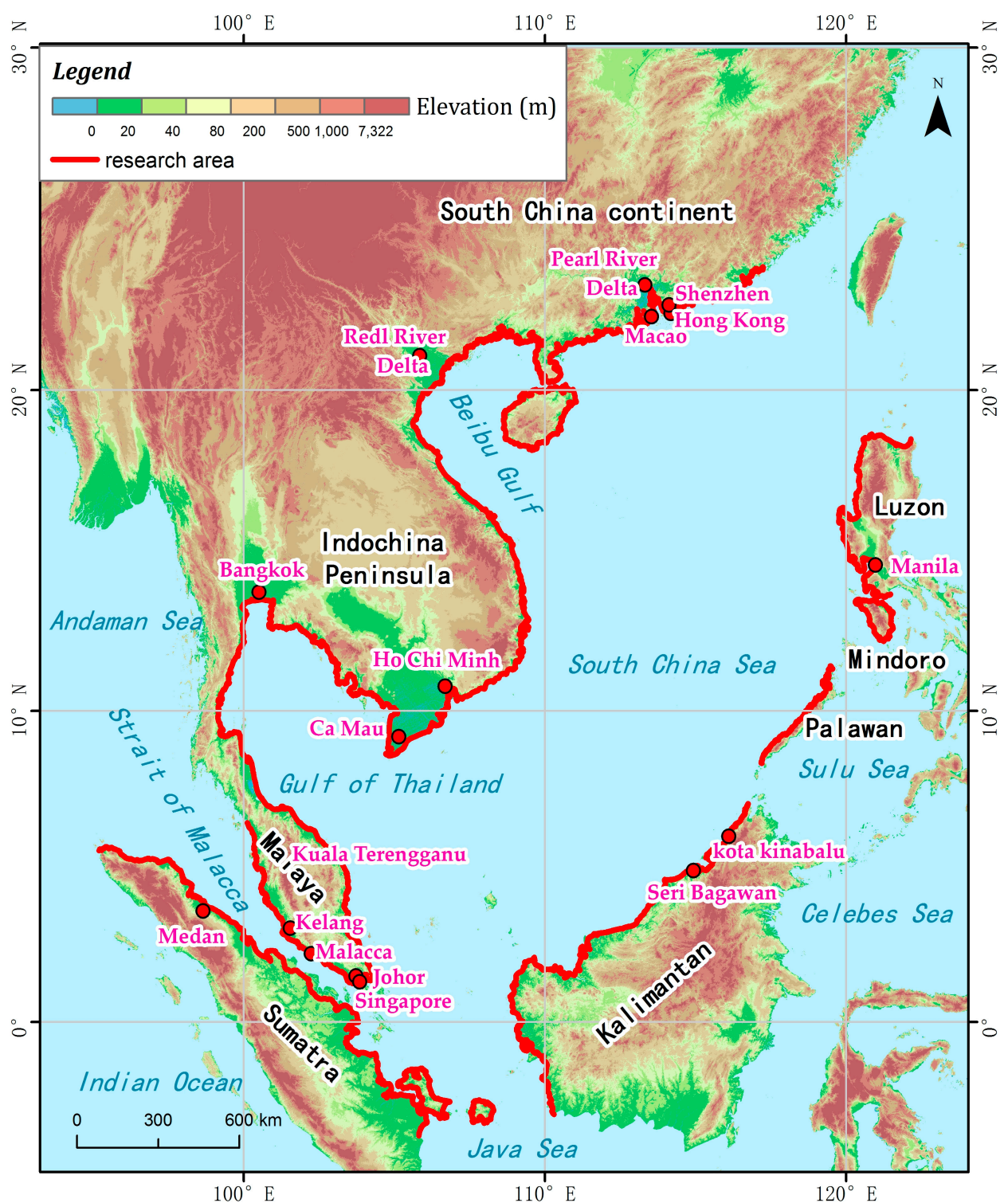

Figure 1. Location of the South China Sea.

Regarding the topography, the alternate distribution of vast plains and hills is the notable feature in the coastal zone of the South China Sea. Four important great rivers (the Pearl River, the Red River, the Mekong River, and the Chao Phraya River) cross over the region. There are two large bays (Beibu Gulf and the Gulf of Thailand) in the north. The Strait of Malacca, Sunda Strait, and Bashi Channel are famous channels, bringing flourishing trade to the ports. The South China Sea has abundant rainfall, perennially high temperatures, good hydrological conditions, plentiful marine fishery resources, and rich oil and gas resources. An abundant natural environment forged the densely-populated and rapidly-developed area.

The research area focused on the coasts of the South China Sea, Gulf of Thailand, and the Strait of Malacca. The total length of the coast is $29,022 \mathrm{~km}$. In addition to continental coastline, only land-tied islands and very large islands (area $>3000 \mathrm{~km}^{2}$ ) were taken into consideration in this thesis. The lengths of the coastline in countries are shown in Table 1. In China, Guangdong Province, Guangxi Province, and Hainan Province were included in the statistics. In Thailand, the coast on the Gulf of Thailand was considered. For Indonesia, it included some coasts of Sumatra and Kalimantan. For the Philippines, it included the west coasts of Luzon, Mindoro, and Palawan. 
Table 1. Length of coastline in research area.

\begin{tabular}{cccc}
\hline Country & Coast Length in the Research Area & Total Coast Length & Proportion \\
\hline China & 6857 & 24,329 & $28 \%$ \\
Vietnam & 4569 & 6761 & $68 \%$ \\
Cambodia & 721 & 1008 & $72 \%$ \\
Thailand & 2517 & 6077 & $41 \%$ \\
Malaysia & 4326 & 7211 & $60 \%$ \\
Singapore & 261 & 347 & $75 \%$ \\
Indonesia & 5785 & 80,041 & $7 \%$ \\
Brunei & 217 & 217 & $100 \%$ \\
Philippines & 3769 & 26,560 & $14 \%$ \\
\hline Total & 29,022 & 152,550 & $19 \%$ \\
\hline
\end{tabular}

\subsection{Data Sources}

The data used in this study include Landsat Multi-Spectral Scanner (MSS) images taken around 1975, and Landsat 5 Thematic Mapper (TM) images and Landsat 7 Enhanced Thematic Mapper Plus (ETM+) images taken in 2010. Data preprocessing included geometric correction, radiometric calibration, gap filling, and image enhancement. The administrative map and DEM map were collected.

\subsection{Sea Reclamation Extraction}

There are three steps to extract sea reclamation information. Firstly, the coastlines of the two periods were extracted; secondly, sea reclamation information was extracted; and, finally, the attributes of the sea reclamation information were assigned.

\subsubsection{Coastline Extraction}

The extraction of the coastline is based on the manual interpretation method according to the features of different types of coastline shown in the images. Coastline can be divided into artificial coast and natural coast, and natural coastline can be subdivided into bedrock coast, sandy coast, silt coast, mangrove coast, and estuary coast. For artificial coast and bedrock coast, coastline is the boundary between water and land; for sandy coast, coastline is the upper limit of the beach ridge trace; for silt coast, coastline lies at the seaward vegetation line, while coastline lies to the landward vegetation line for mangrove coast. Estuary coast is located at the sudden narrowing of the river. When the coastlines of two periods were extracted, topological correction of the coastlines was performed.

\subsubsection{Sea Reclamation Extraction}

Sea reclamation extraction was achieved by the cut of two-phase coastlines. Firstly, the ends of the coastline were connected and the coastline data was used to generate the polygon shapefiles in ArcGIS (developed by ESRI Company in America). Secondly, the two polygon shapefiles were clipped and the new polygon shapefile was obtained, indicating the sea reclamation information. Finally, reclamation correction was conducted. According to the area of the polygon, small polygons which were less than $900 \mathrm{~km}^{2}(3 \times 3$ pixels) were removed. The aspect ratio of the minimum bounding rectangle of the polygon was used to eliminate the long and narrow polygons caused by the error of the coastline extraction. After two rounds of screening, the remaining polygons were checked and corrected manually on the remote sensing images.

\subsubsection{Attribute Assignment}

Sea reclamation polygons were assigned from the TM/ETM+ images in 2010. Attributes were divided into five classes: fish farming, farmland, construction, docks, and airports. For the unused land (sea area which has been embanked but not yet used), a simple treatment was applied, as they 
were few. The unused land was assigned on the basis of the recent images. The specific introduction is shown in the Table 2.

Table 2. Classification of sea reclamation and their meanings.

\begin{tabular}{cl}
\hline Type & \multicolumn{1}{c}{ Description } \\
\hline Fish farming & Construct embankments on coastal mudflat for fish farming \\
Farmland & Enclose the sea for agriculture land \\
Docks & Use earthworks etc. to fill the sea into land for docks \\
Airports & Fill the sea into land for airports \\
Construction & Fill the sea into land for residences, traffic, and industry, except docks and airports \\
\hline
\end{tabular}

\section{Results}

\subsection{General Overview of Sea Reclamation}

Statistics on the reclamation information of the South China Sea from 1975 to 2010 were calculated. The result showed that the total new area of sea reclamation reached $3264 \mathrm{~km}^{2}$ in 35 years, almost four times the area of Singapore Island. The average annual growth rate was nearly $93 \mathrm{~km}^{2}$. Among them, the area of sea reclamation in Vietnam reached $1586 \mathrm{~km}^{2}$, almost half of the total area (Figure 2). Sea reclamation in China was also significant, at about $1044 \mathrm{~km}^{2}$, which occupies one third of the total reclamation area. This indicated that the demand and size for sea use in Vietnam and China was great, largely outweighing the overall level. Newly-reclaimed land in Indonesia added up to $306 \mathrm{~km}^{2}$, which was also notable. The results of sea reclamation area in Malaysia and Singapore were similar, about $120 \mathrm{~km}^{2}$ or so. A noteworthy phenomenon was that although the area of sea reclamation in Singapore was not too large in all of the surrounding countries, it accounted for 15\% of Singapore Island. This was a rather high proportion, even at a global level. The proportion of sea reclamation in the remaining countries (Cambodia, Thailand, and Brunei) was low, accounting for less than $2 \%$.

From the land-use types, the size of sea reclamation structure was not balanced (Figure 3). Sea reclamation for fish farming was the major type in the whole sea from 1975 to 2010, and the area of which was $2493 \mathrm{~km}^{2}$, taking up $76.4 \%$ of the total new area. Secondly, the amount of sea reclamation for construction and docks were also large. The proportion accounted for $11.6 \%$ and $7.8 \%$, respectively, and the area were 380 and $253 \mathrm{~km}^{2}$. By comparison, sea reclamation for farmland and airports occupied a low proportion, both less than $3 \%$.

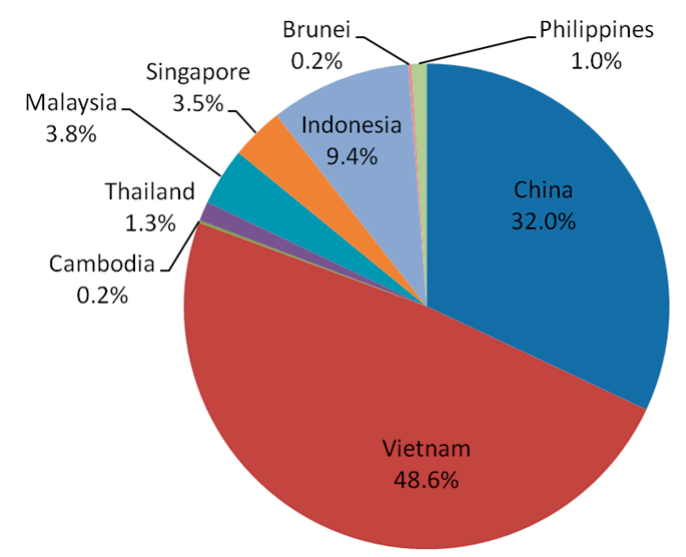

Figure 2. Sea reclamation in countries. 


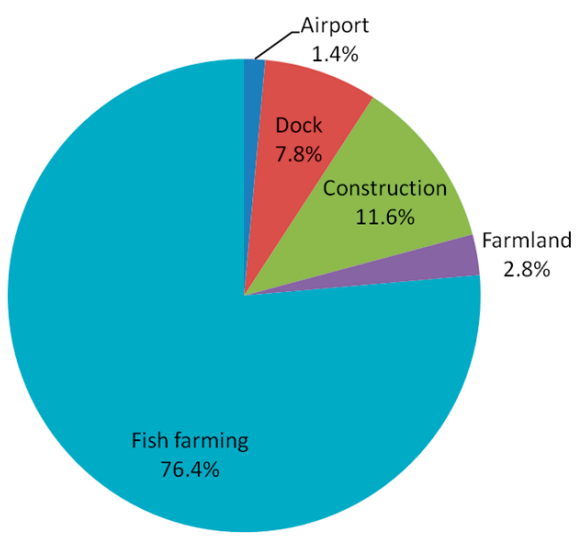

Figure 3. Sea reclamation of different land-use types.

Statistics on the reclamation information in each administrative area were calculated. From the spatial distribution, sea reclamation was quite different on the east and west sides of the South China Sea. Area in the west was notably higher than the east. New areas of sea reclamation were centered in the South China mainland, North Beibu Gulf, Ca Mau Peninsula, and the Strait of Malacca (Figure 4). From the administrative district, sea reclamation in different provinces (states) varied remarkably. Among them, sea reclamation area in Ca Mau, Vietnam was the largest, at about $1062 \mathrm{~km}^{2}$, accounting for one third of the total area. Guangdong Province in China followed, with an area of $866.7 \mathrm{~km}^{2}$. Sea reclamation in Aceh, Indonesia; Quang Ninh, Vietnam; Guangxi, China; and Singapore was relatively high, the areas of which were $145.6,140.6,114.3$, and $112.8 \mathrm{~km}^{2}$. In most provinces, sea reclamation area was very low.

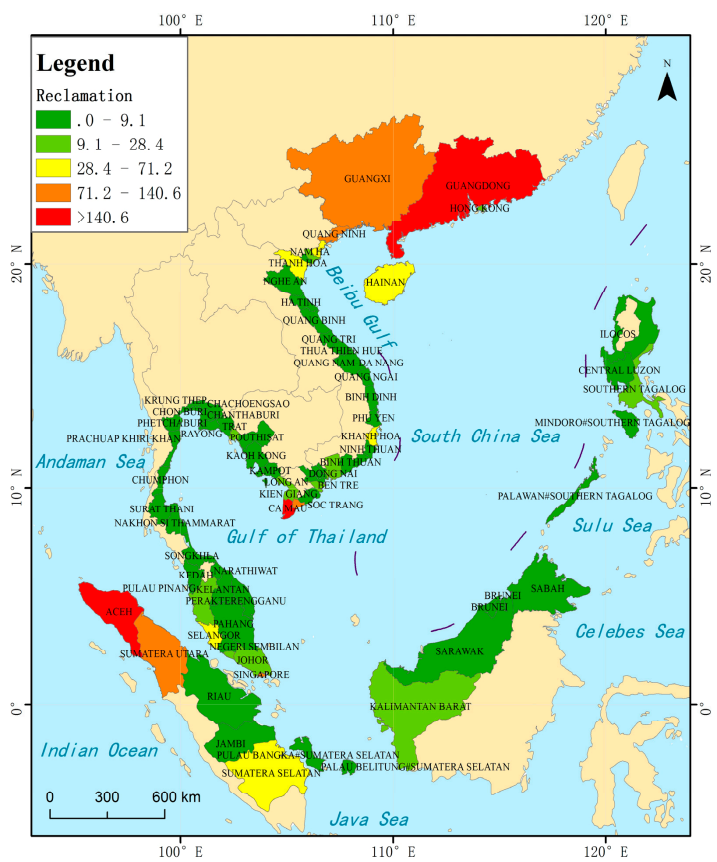

(a)

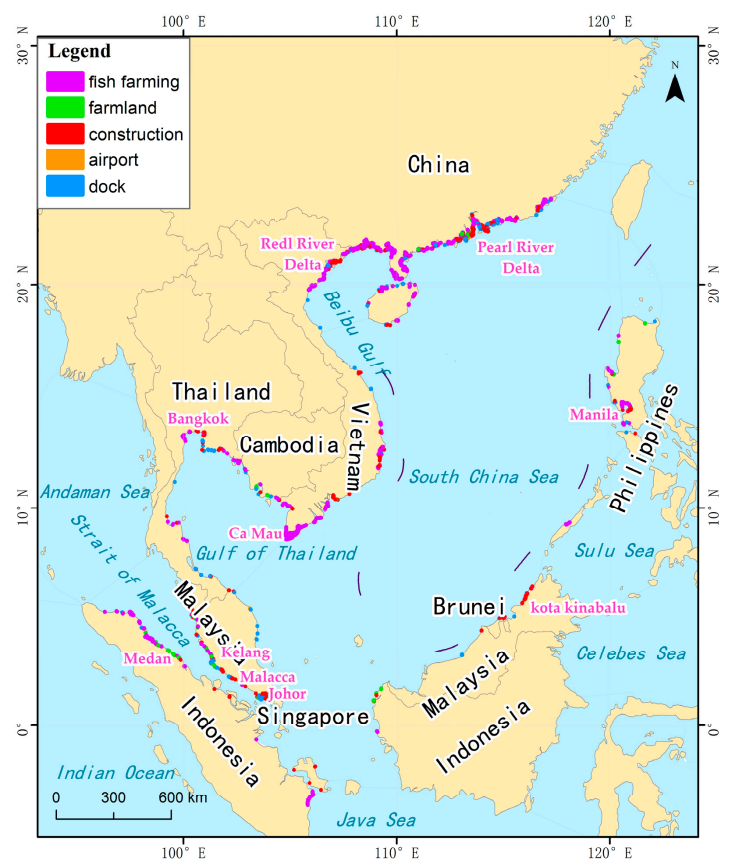

(b)

Figure 4. Distribution of sea reclamation in the South China Sea from 1975 to 2010. (a) Distribution by administrative district. (b) Distribution by reclamation types(Sea reclamation represents location, not area). 
From the distribution of sea reclamation of different land-use types, sea reclamation for fish farming was widely distributed in the whole area. The most concentrated areas were located on two coasts. One stretched from the eastern boundary of Guangdong Province, China to the Red River Delta, Vietnam. The other one was in the Ca Mau Peninsula. The distributions of sea reclamation for construction and docks were similar, mainly in the Pearl River Delta, Beibu Gulf, and Singapore Island. Sea reclamation area for farmland was lower, centered in West Pearl River Delta and Sumatera Utara, Indonesia. Finally, there were five places of sea reclamation for airports, located in Shenzhen, Zhuhai, Macau, China; Kuala Terengganu, Malaysia; and Singapore. Among them, Macau Airport was almost entirely constructed by sea reclamation. Half of the area of Shenzhen Airport and Singapore Changi Airport were constructed through sea reclamation.

\subsection{Sea Reclamation between Countries}

From the land-use types, area, and type composition of sea reclamation in different countries varied greatly (Figure 5). According to the area of sea reclamation, areas for fish farming were located mostly in China, Vietnam, and Indonesia. Especially in China and Vietnam, sea reclamation for fish farming covered an area of 673 and $1511 \mathrm{~km}^{2}$, respectively. Similarly, sea reclamation areas for construction were mainly distributed between China and Vietnam. The areas were 202 and $68 \mathrm{~km}^{2}$, respectively. For sea reclamation for docks, China, Malaysia, and Singapore held a dominant role, and the areas were 128, 61 and $56 \mathrm{~km}^{2}$. In Indonesia and China, sea reclamation areas for farmland were mainly distributed. According to the proportion of sea reclamation, sea reclamation for fish farming was the main type in China, Vietnam, and Indonesia. With respect to sea reclamation for construction, it prevailed in Brunei and the Philippines. In Malaysia and Singapore, the proportion of sea reclamation for docks was the largest. For farmland, it belonged to Cambodia.

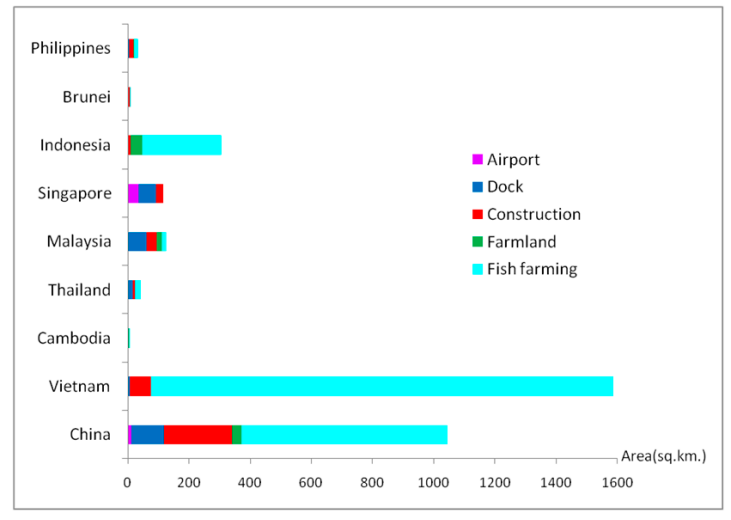

(a)

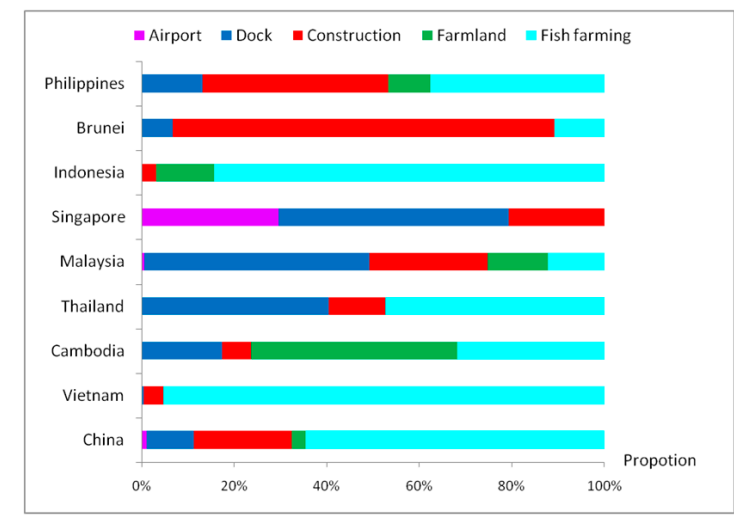

(b)

Figure 5. Sea reclamation of different types by country. (a) Area of sea reclamation. (b) Proportion of sea reclamation.

Distributions of sea reclamation are different between countries (Figure 4). In China, sea reclamation was widely distributed in the coastal zone, especially in Guangdong Province. Sea reclamation in Guangdong Province covered a total area of $867 \mathrm{~km}^{2}$, over $80 \%$ of the total new area. Meanwhile, the patch area of sea reclamation was relatively large and it showed significantly banded distributions. In Guangxi and Hainan Province, sea reclamation patches were scattered and cracked. Sea reclamation for fish farming was the main type, followed by sea reclamation for construction and docks. The areas were 673,272 , and $128 \mathrm{~km}^{2}$. In China, the coastline was sinuous and irregular, with numerous bays. Sea reclamation for fish farming was evenly distributed in the large and small bays. Among them, the west coast of the Pearl River Mouth and Lei Zhou Peninsula were the most distinctive ones. For construction, it was centered on the both sides of the Pearl River Mouth, covering more than $50 \%$ 
of the total area. Sea reclamation areas for docks were mainly located in Daya Bay, Dapeng Bay, Pearly River Estuary, Huangmao Bay, Qinzhou Bay, and Fangcheng Bay. The distribution of sea reclamation for farming was relatively smaller, concentrated in Qingshui Bay, Zhongshan, and Huangmao Bay, and Jiangmen on the west coast of the Pearl River Mouth.

In Vietnam, sea reclamation was relatively concentrated in distribution. The Red River Delta and the North Highland, the southeast coast of Changshan Mountains, and the Ca Mau Peninsula were the dense distributions. Among them, sea reclamation in the Ca Mau Peninsula was the most dramatic, followed by the Red River Delta and the North Highland. The type composition of sea reclamation in Vietnam was simple. Sea reclamation for fish farming was the main type and the proportion exceeded $95 \%$. The area was also very impressive, about $1511 \mathrm{~km}^{2}$. Fish farming in Vietnam grew rapidly and this was achieved by expanding the area to increase the production. The locations for fish farming were located in estuarine delta regions and bays. Sea reclamation for construction was mainly located in Ha Long Bay and the Cam Pha area. Ha Long Bay was a beautiful and charming bay in Quang Ninh. Stimulated by the tourism industry, the demand of expanding for construction increased. Sea reclamation in Cam Pha was mainly stimulated by the coral industry. The areas of reclaimed land were 20 and $11 \mathrm{~km}^{2}$.

Cambodia held fewer coast resources with a low degree of exploration. The area of sea reclamation was the smallest of all the surrounding countries, at just $5 \mathrm{~km}^{2}$. Sea reclamation for farmland and fish farming were the main types and the areas of the two were close. In Thailand, sea reclamation was also not prevalent, with a total area of $42 \mathrm{~km}^{2}$. The main distributions were in the Bangkok Bay and the east side. The southern coast had rare reclaimed land. Sea reclamation for fish farming and docks were the main types. Fish farming was developed in Thailand, but the new area of sea reclamation for fish farming was not significant. The area was $20 \mathrm{~km}^{2}$, just one twentieth of the reclamation area for fish farming in Vietnam.

Sea reclamation was dramatic in Malaysia, and unlike the above countries, there was less sea reclamation area for fish farming. Sea reclamation for construction and docks were the main types. The distributions were scattered in the two peninsulas. Overall, sea reclamation in West Malaysia far outweighed sea reclamation in East Malaysia. In West Malaysia, sea reclamation on the west coast of the Malay Peninsula was more dramatic than the east coast. Sea reclamation in Selangor State was the most dramatic and newly-reclaimed land reached $64 \mathrm{~km}^{2}$. Especially in Kelang, Kelang Port was wholly built on Pulau Indah (a mangrove island) wholly through sea reclamation. Perak State and Johor State followed. In East Malaysia, sea reclamation was mainly distributed in Kota Kinabalu, Sabah.

Singapore occupied the highest level of sea reclamation. The area of Singapore Island was increased by $114 \mathrm{~km}^{2}$. In the southwest coast, southeast coast, and northeast coast, large-scale reclamation works took place. Sea reclamation for docks took up over $50 \%$ of the total new area and occurred mostly in the southwest coast.

In Indonesia, sea reclamation in Sumatra was more dramatic than Kalimantan. Sea reclamation for fish farming was the main type, followed by farmland. Newly-reclaimed land was concentrated in Aceh and Sumatera Utara, which is on the west coast of the Malacca Strait. In Brunei, sea reclamation for construction occupied an absolutely dominant position. The reclaimed land was distributed mainly in Bandar Seri Begawan and caused the loss of mangroves. In the Philippines, sea reclamation for fish farming and construction were the main types. The areas were densely distributed in the two largest bays of Luzon Island: Manila Bay and Lingayen Gulf.

\subsection{Sea Reclamation in Typical Areas}

\subsubsection{Typical Estuarine Delta}

The Pearl River Delta is located along the sea in the central part of Guangdong Province (Figure 6). As a large tropical estuarine delta, the Pearl River Delta has abundant bifurcate rivers, and many entrances and shallows, and is easy for sea reclamation. Meanwhile, vast land area, a convenient water 
system, and the large trade port of Guangdong as the hinterland, leads the Pearl River Delta as the key area of China's economic development. Since the reform and opening up in the 1970s, as the gateway in the South China region opening to the Southeast Asia area, the economy of the Pearl River Delta has developed rapidly and the demand for the sea has increased as well. Sea reclamation in the region (Huangmao Sea to the west and east to Daya Bay) covered a total area of $558 \mathrm{~km}^{2}$, more than $50 \%$ of the total reclamation area in China. From the land-use types, sea reclamation for fish farming dominated and the area reached $309 \mathrm{~km}^{2}$. Sea reclamation for construction followed, covering $164 \mathrm{~km}^{2}$. The areas of sea reclamation for docks and farmland were 44 and $30 \mathrm{~km}^{2}$, respectively. From the distribution, the largest-scale works occurred in Zhuhai, followed by Shenzhen and Jiangmen. In Gaolan Island, Sanzao Island, and Hengqin Island, in Zhuhai, sea reclamation works filled in the sea which connected the continent and islands.

From the landform, the Pearl River Delta is a complex estuarine delta composed of the Xijiang River, the Beijiang River, and the Dongjiang River. Additionally, the Pearl River Estuary (Linding Sea) presents a landscape of the drowned harbor coast. The landforms at the two sides of the Pearl River Delta are quite different. Most entrances are concentrated on the west bank, including Yamen, Modaomen, and Jiaomen. Thus, most regions are alluvial plains and shoals, with few low hills in Zhuhai and Jiangmen. On the east bank, it is a complex landscape scheme in which hills and platform dominate with some piedmont alluvial plains. Only the Humen entrance lies in the east bank, yet most bays are located in the region, such as Shenzhen Bay, Dapeng Bay, and Daya Bay. Different landforms contribute to the spatial variation of sea reclamation. Overall, the area of sea reclamation on the west bank was higher than the east. Sea reclamation areas for fish farming occurred mainly on the west bank, such as Yamen, Modaomen, Jinxing Bay, Hongqimen, and Jiaomen. Meanwhile, the patch area of fish farming was relatively large. Large-scale reclamation misappropriated most waterways and affected shipping. Sea reclamation areas for docks occurred mainly in the bays of the east bank, such as Qianhai Bay, Dapeng Bay and Daya Bay. Sea reclamation areas for construction were scattered in distribution, mainly occurring on offshore islands, waterways, and bays. In Huangmao Bay, Maliuzhou Waterway, Dangzi Island, Qianhai Bay, and Shenzhen Bay represent several reclamation projects were conducted.

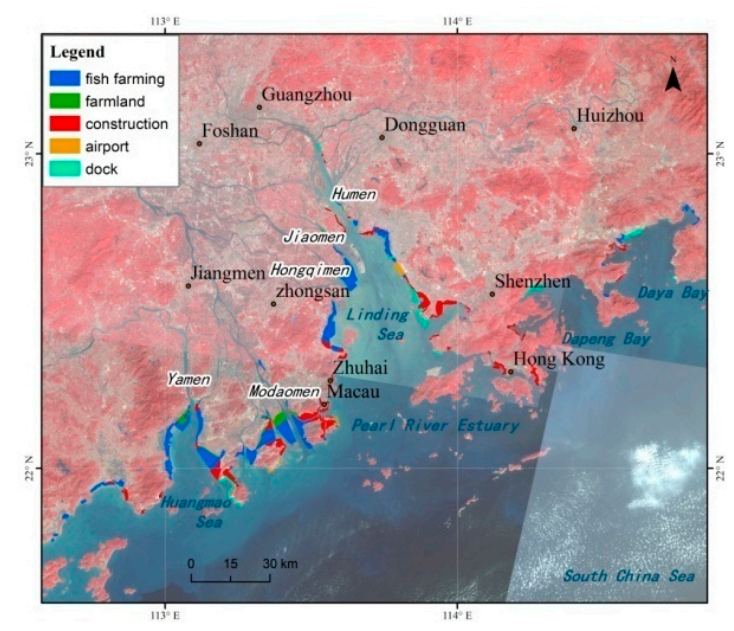

(a)

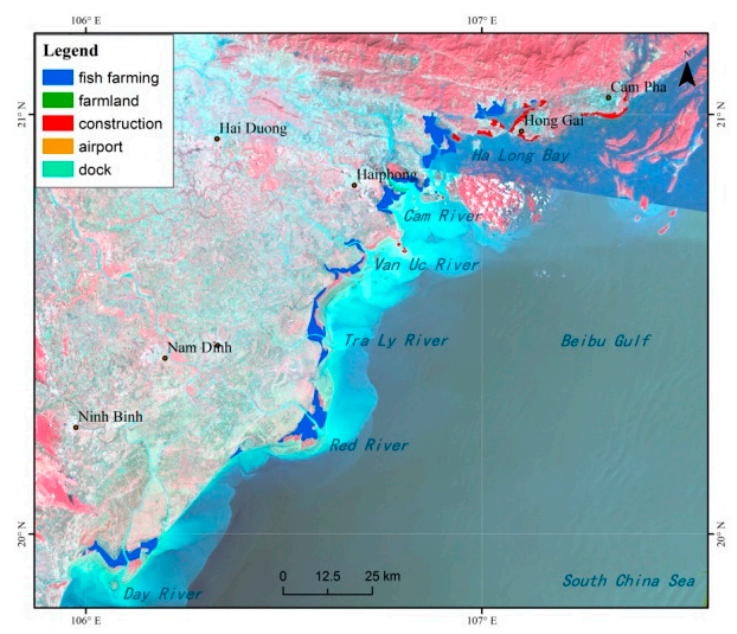

(b)

Figure 6. Sea reclamation in estuarine deltas. (a) Sea reclamation in the Pearl River Delta. (b) Sea reclamation in the Red River Delta.

The Red River Delta has been developed in Northern Vietnam, opening up to the Beibu Gulf. It is composed of the Red River and its streams. Alluvial plain is the major geomorphologic type. With dense river networks, the surrounding land in the Red River Delta is low with widespread shoals and tidal mangrove forests. The type of sea reclamation was simple. Newly-reclaimed land for fish farming was $221 \mathrm{~km}^{2}$, over $95 \%$ of the total new area in the delta. In distribution, it occurred mainly in the river 
mouths, including Da Bach River, Cam River, Van Uc River, Thai Binh River, Tra Ly River, Hong River, and Day River, from north to south. Additionally, the patch area of reclaimed land was relatively large. Due to sea reclamation for fish farming, mangroves in the Red River Delta had been severely damaged and the area was drastically reduced. Furthermore, newly-reclaimed land for docks was located in Hai Phong, which is the outport of Hanoi. It is an estuary harbor in the Cam River Mouth.

\subsubsection{Typical Bays}

Qinzhou Bay and adjacent bays are drowned bays in Beibu Gulf, China (Figure 7). The total area of reclaimed land added up to $74 \mathrm{~km}^{2}$. Among them, Qinzhou Bay and Fangcheng Bay are mountain-drowned bays which are suitable for dock construction. Newly-reclaimed land was rather considerable, with about 13 and $20 \mathrm{~km}^{2}$, respectively, reclaimed for Fangchenggang dock and Qinzhou dock. In the Maowei Sea and Dafengjiang River, where mangroves grew thickly, sea reclamation for fish farming occurred.

Bangkok Bay is the largest bay in Thailand, standing at the outlet of the Chao Phraya River. Reclaimed land in the bay (including Rayong) added up to $25 \mathrm{~km}^{2}$. Sea reclamation for fish farming was located mostly on the west side of Bangkok Bay in a banded distribution. In contrast, sea reclamation for docks (Laem Chabang and Rayong) was located on the east side of Bangkok Bay. The reclaimed land areas for docks were 6 and $5 \mathrm{~km}^{2}$, respectively. The natural environments of both sides of the bay are also different. On the west side, alluvial plain is the main geomorphologic type and silt-mangrove coast is the main coast type, which is suitable for fish farming. On the east side, the terrain is higher with bedrock-sandy bays-matching the conditions for dock construction.

Manila Bay is a large natural harbor on Luzon Island. The western and southern parts are surrounded by peninsulas. In the north, there is a large marsh delta for fish farming. New land for fish farming was small and the distribution was scattered. A relatively large reclamation project occurred on the west coast of Pasay City. A block of $8 \mathrm{~km}^{2}$ was reclaimed for building construction. Sea reclamation for docks was also not notable as the demand for trade was limited. Several projects had been completed in the estuary of the Vitas River.

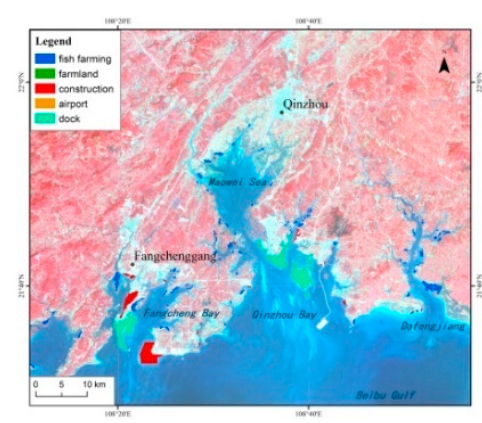

(a)

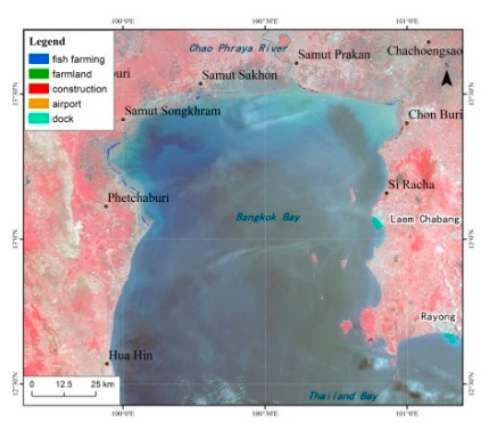

(b)

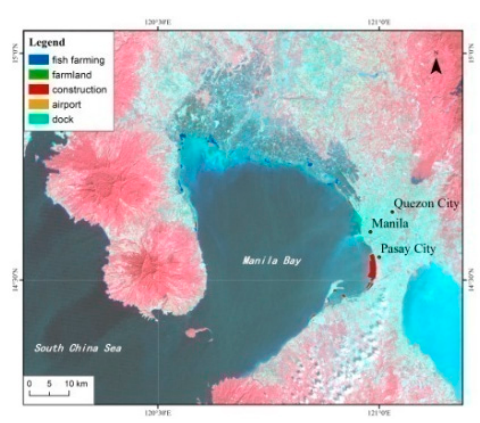

(c)

Figure 7. Sea reclamation in bays. (a) Qinzhou Bay; (b) Bangkok Bay; (c) Manila Bay.

\subsubsection{Typical Offshore Islands}

Macau lies on the west coast of the Pearl River, adjacent to Zhuhai (Figure 8). It is a famous international commercial center with a dense population and prosperous economy. Due to the lack of land surface area and its mountainous topography, Macau has a long history of sea reclamation. Influenced by the streams of the West Pearl River, sediment deposition of the coast in Macau is serious and brings about a large number of shallows. This reduces the costs of sea reclamation. From 1975 to 2010, reclamation of land from the sea in Macau covered a total are of $13.7 \mathrm{~km}^{2}$, close to its original area. Most reclamation areas were used for construction; about $11.6 \mathrm{~km}^{2}$. The north coast of the Macau Peninsula moved seaward by nearly one kilometer. Dangzai Island and Luhuan Island were connected by the large scale of land reclamation. On the east coast of Dangzai Island, an airport was built entirely 
through sea reclamation. Again, due to the sediment deposition, no large docks occurred in the region. The only dock through reclamation lay on the north coast of Dangzai Island.

Singapore lies to the south of the Malay Peninsula, near the outlet of the Malacca Strait. As the fortress connecting the Indian Ocean and the Pacific Ocean, Singapore has an excellent geographical location. Since the area of Singapore Island is limited, sea reclamation projects have been carried out intensely since the independence of Singapore to meet the needs of economic development. The area of Singapore Island has increased from 629 to $743 \mathrm{~km}^{2}$ from 1975 to 2010. Large-scale reclamation works occurred in the southwest, northeast, and southeast coasts. Sea reclamation for docks predominated. The main dock works were on the southwest coast and adjacent offshore islands. Seven small islands were reclaimed into one larger island-Jurong Island-for expanding the petrochemical industry. The whole port scale was rather large, covering a total area of $50 \mathrm{~km}^{2}$. It was also the largest port in the South China Sea region. Sea reclamation for construction occurred on the northeast and southeast coasts. The continued sea reclamation project in the northeast caused the decrease in the water area of the Johor Strait and affected navigation. The largest airport—Singapore Changi Airport—was also constructed by reclamation on the east coast.

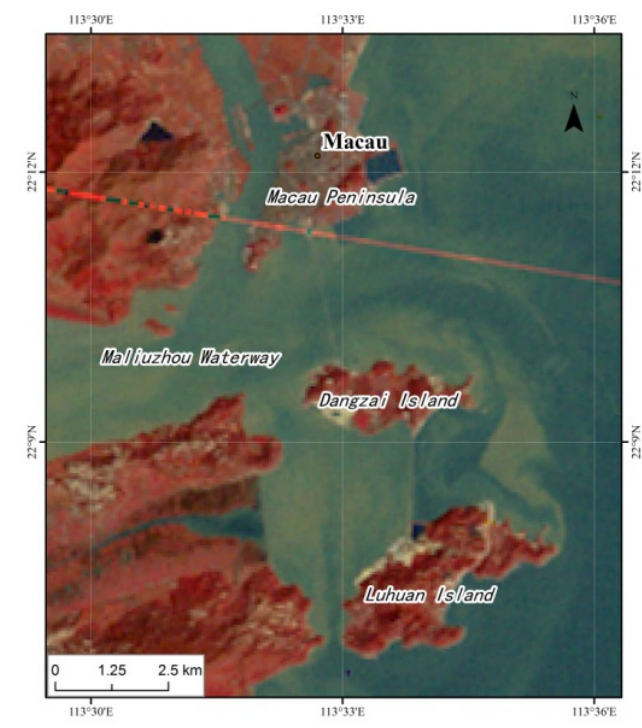

(a)

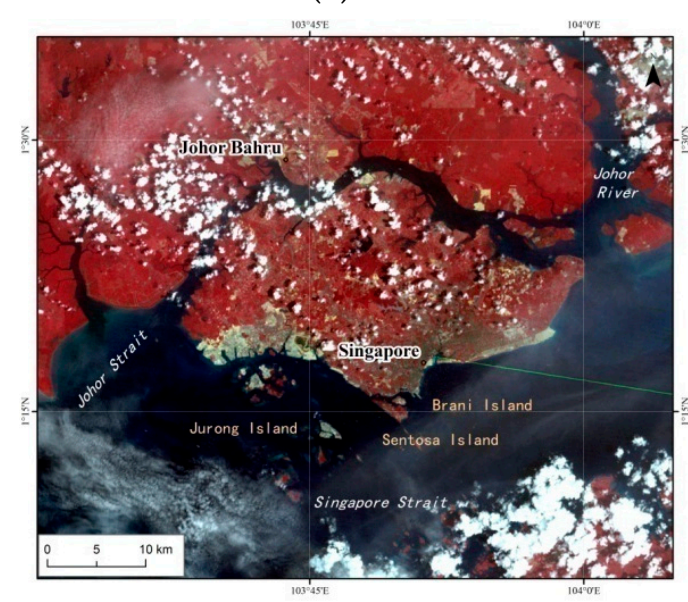

(c)

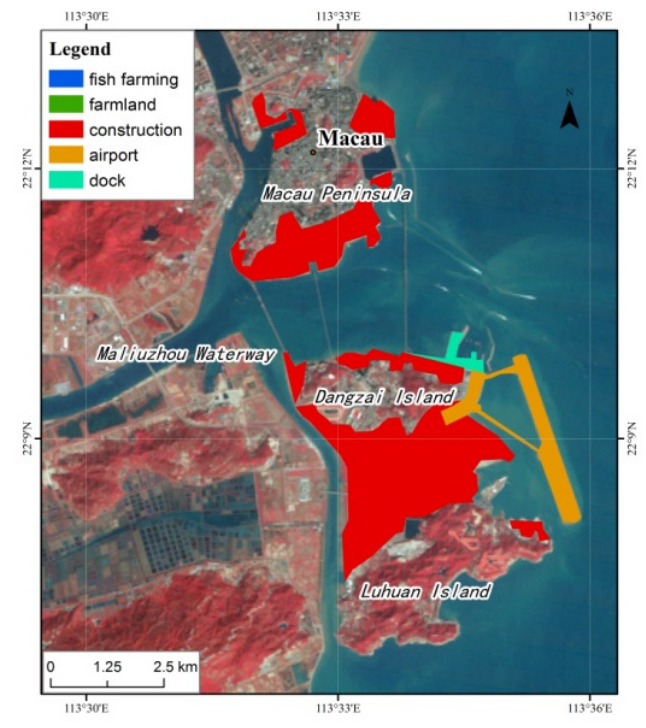

(b)

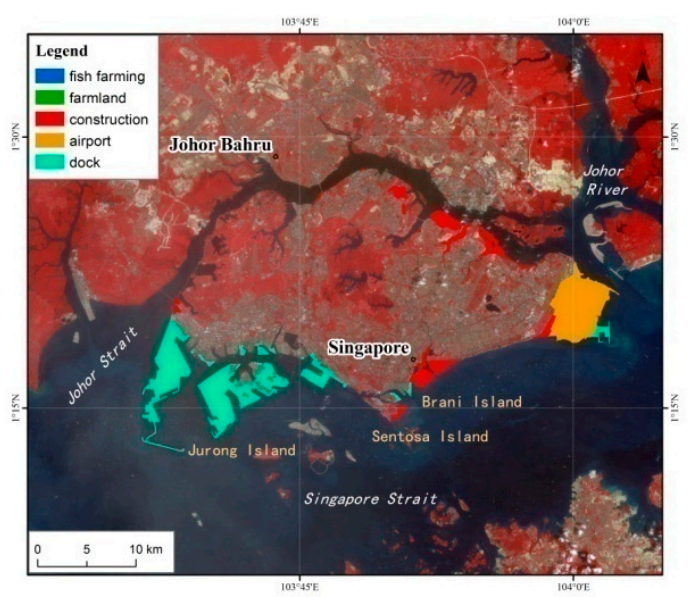

(d)

Figure 8. Sea reclamation of offshore islands. (a) Macau in 1975. (b) Macau in 2010. (c) Singapore in 1975. (d) Singapore in 2010. 


\section{Discussion}

Economic policy and land supply factors contributed to sea reclamation. Since the 1970s, countries around the South China Sea have faced the acceleration of population and economic development. According to the statistics of the World Bank [25], the total population of the nine countries in the research area had increased by more 50\% from 1975 to 2010. Meanwhile, the total GDP had increased by 30 times. As the key areas of economic development and population centers, turning the sea into land is unstoppable in coastal zones. Among the countries examined, sea reclamation in China, Vietnam, and Singapore was the most dramatic.

For Singapore, the increase of new reclaimed land was due to economic growth and land shortages. As an island country, the sea is a national resource upon which Singapore's well-being depends to a large extent on the country's limited sea space [10]. Reclamation for housing and industry was one of the main coastal development activities [26]. After Singapore separated from Malaysia in 1965, the economics of Singapore advanced rapidly. The GDP increased from 0.97 billion dollars in 1965 to 236 billion dollars in 2010. The growth speed was the largest of the nine countries examined. Large-scalel and reclamation projects occurred to meet the urgent and growing needs of housing, commercial, industrial, infrastructure, and recreational development. The Tuas Reclamation Project, Jurong Industrial Estate Project, and Changi Airport Project were conducted in recent decades.

This is also the case for China. Since the result of reforms and the "opening up" policy in 1978, China's economic growth rate is accelerating. In 2010, the GDP of China (including Hong Kong and Macao) held 76.7\% of the total GDP. In the 10th, 11th, and 12th Five-Year Plans of China from 2001 to 2011, the development of the marine economy has been put forward with emphasis "to thrive the city by relying on the port". At the forefront of opening up, the southeast coast faced a serious conflict between economic development and limited land [27], as there were large hills and less plain in the South China continent. At the same time, the corresponding laws and regulations were not perfect, causing the situation of large-scale disordered sea reclamation. Sea reclamation in China had the notable features of large scale, large area, and diversified utilization.

As a major power of sea reclamation, the increase of sea reclamation in Vietnam was stimulated mainly by fish farming. Compared with other countries, the ratio of agriculture GDP (together with forest and fishing) to total GDP was much higher [28]. In agriculture, fish (inland fish farming and marine catching) production value had increased rapidly. In 2010, aquaculture production in Vietnam rose to third, globally, (behind only China and India) [29]. The growth of fish farming was particularly fast; up to 2007, the production of fish farming was equal to that of marine catches. The increase of production was achieved by expanding the area for fish farming on shoals and mangroves to a great extent. In the two large estuarine deltas (the Red River Delta and the Mekong River Delta), especially the latter, new land for aquaculture had a significant impact.

In the remaining countries, sea reclamation was not notable. First, the growth of GDP in such countries was lower and land supply was relatively adequate compared to Singapore and China. Second, sea reclamation for fish farming was the main type in coasts around the South China Sea. However, in Thailand, Malaysia, Brunei, and the Philippines, aquatic products were mainly from marine fisheries and fish farming accounted for a small proportion [30,31]. The growth of fish farming was relatively low, which had little demand for new reclaimed land. Third, some main fish farming areas were not in the scope of the research area. In the Philippines, a significant number of culture ponds were distributed in the Visayas Islands and Mindanao [32]. In Indonesia, the main fish farming areas were located on Java Island.

Except for the above factors, landscapes influence sea reclamation significantly. Bays, estuaries, and offshore islands are primary choices. Most of new reclaimed land takes place in such areas. According to the type of sea reclamation, the distributions are different. Countries around the South China Sea own rich shoal and mangrove resources, which are suitable for fish farming. As the main reclamation type, new reclaimed land for fish farming was located mainly on the silt coast, in areas such as estuarine coasts and muddy bays. The west coast of the Pearl River Delta, the Red River Delta, 
the Mekong River Delta, and the east coast of Sumatera Utara were the main areas. For construction, bays or offshore islands are good choices. In bays, such as Shenzhen Bay, Tseung Kwan, and Ha Long Bay, and offshore islands, such as Dangzai Island and Sentosa Island, new reclaimed land for construction occurred. For docks, new reclaimed land was distributed in bedrock bays, drowned bays, or estuaries owing to good conditions conducive to sheltering from the wind, such as Daya Bay, Qinzhou Bay, Cam River Mouth, Kelang River Mouth, and Pulai River Mouth.

Although sea reclamation brings about abundant economic profits, the impact of reclamation is felt in many ways, including mangrove loss, fishery decline, and shipping impact. Mangrove is one of the marine ecosystems with the highest productivity, contributing significantly to the maintenance of biodiversity and the improvement of the ecological environment. Mangrove is widely distributed in the South China Sea, especially in the vast area of the Mekong River and the Strait of Malacca. Due to sea reclamation for aquaculture ponds, the loss of mangrove is serious. In Aceh Province of Indonesia, the construction of ponds destroyed large areas of mangroves. With the loss of mangrove protection, the coastal zone is vulnerable to natural hazards, such the tsunami in 2004. In Ca Mau Province of Vietnam, new shrimp culture ponds added up to $1062 \mathrm{~km}^{2}$. They were constructed absolutely in the mangrove area. The loss of mangrove exceeded 70\% [33]. In Ha Long Bay of Vietnam, the extent of sea reclamation was great and newly-reclaimed land added up to $32 \mathrm{~km}^{2}$. The consequential reduction in mangrove is amazing, at over two thirds of the original mangrove area. The same situation occurred in Hai Phong, Vietnam, and Pulau Indah, Malaysia. [34-36]. In Tieshangang Bay and Zhenzhugang Bay of China, the environments of the two famous pearl cultivation bases were seriously destroyed due to large-scale sea reclamation works for dock construction. Now it was no longer suitable for pearl cultivation [37]. Sea reclamation in the northeast coast of Singapore resulted in a narrowing of the Johor Channel between the two countries, impacting upon ships' entry to Johor's eastern port at Pasir Gudang. Additionally, it caused disputes of territorial sovereignty between Singapore and Malaysia [38].

\section{Conclusions}

With rapid population growth and economic development since the 1970s, countries around the South China Sea have steadily taken up large-scale sea reclamation activities. The total area of sea reclamation increased by $3264 \mathrm{~km}^{2}$ from 1975 to 2010. Aquaculture was the dominant factor and the proportion of new reclaimed land used for fish farming exceeded $75 \%$. Urban development (construction, docks, and airports) was the second dominant factor, while agriculture accounted for a slight proportion. Sea reclamation in China, Vietnam, and Singapore was significant owing to economic stimulation. China accounted for $32 \%$ of the total new reclaimed land and presented the features of large patch areas, large scale, and diversified utilization. Vietnam accounted for $48.6 \%$ of the total new reclaimed land and fish farming was the main land-use type. Approximately $15 \%$ of Singapore's area was acquired by sea reclamation for urban and industry development.

Moderate sea reclamation can give time for the marine environment to recover as it creates economic profits. However, sea reclamation at too fast a pace may cause serious damage to the environment. One important reason for the mangrove loss can be traced to cultural pond construction. It was especially prominent in Vietnam. Due to sea reclamation, mangrove degradation was particularly devastating in the Red River Delta and the Mekong River Delta, especially in the latter. The same problem exists on the southern coasts of China and the coasts of the Malacca Strait (Malaysia and Indonesia).Controlling the scale of reclamation and giving consideration to ecological protection should be considered.

Acknowledgments: This study was funded by the National Science Foundation of China (Grant Number: 41421001).

Author Contributions: Junjue Zhang, Fenzhen Su, and Zhi Ding wrote the paper.

Conflicts of Interest: The authors declare no conflict of interest. 


\section{References}

1. MacKinnon, J.; Verkuil, Y.I.; Murray, N. IUCN situation analysis on East and Southeast Asian intertidal habitats, with particular reference to the Yellow Sea (including the Bohai Sea). Occas. Pap. IUCN Species Surviv. Comm. 2012, 70, 47.

2. Jones, G.W. Southeast Asian urbanization and the growth of mega-urban regions. J. Popul. Res. 2002, 19, 119-136. [CrossRef]

3. Masron, T.; Yaakob, U.; Ayob, N.M.; Mokhtar, A.S. Population and spatial distribution of urbanisation in Peninsular Malaysia 1957-2000. Geogr. Malays. J. Soc. Space 2012, 8, 20-29.

4. Liu, Z.; Huang, H. Tempo-spatial characteristics of interactions among changes in built-up land, GDP and demography in the Pearl River Delta. Resour. Sci. 2015, 37, 1394-1402.

5. Zhang, J.; Su, F.; Zhou, C.; Zuo, X.; Ding, Z.; Li, H. Construction land expansion in coastal zone around the South China Sea based on different geomorphologic backgrounds in the past 35 years. Acta Geogr. Sin. 2016, 71, 104-117.

6. Hoeksema, R.J. Three stages in the history of land reclamation in the Netherlands. Irrig. Drain. 2007, 56, S113-S126. [CrossRef]

7. Dore, R. Land Reform in Japan; A\&C Black: London, UK, 2013.

8. Qi, Y.; Wei, X.; Heng, H.; Zhang, J. The Development and Characteristics of Reclamation in the World. Ocean Dev. Manag. 2015, 6, 001.

9. Glaser, R.; Haberzettl, P.; Walsh, R.P.D. Land reclamation in Singapore, Hong Kong and Macau. Geo. J. 1991, 24, 365-373. [CrossRef]

10. Yong, K.Y.; Lee, S.L.; Karunaratne, G.P. Coastal reclamation in Singapore: A review//Urban Coastal Area Management: The Experience of Singapore. ICLARM Conf. Proc. 1991, 25, 59-67.

11. Jasni, A.; Alatas, S.M.; Abdullah, S.M.S. Correlation analysis of Singaporean land reclamation towards its national population. e-BANGI 2015, 10, 1-15.

12. Liu, W.; Liu, B. Current Situation and Countermeasures of Sea Reclamation in China. Guangzhou Environ. Sci. 2008, 23, 26-30.

13. Gao, Z.; Liu, X.; Ning, J.; Lu, Q. Analysis on changes in coastline and reclamation area and its causes based on 30-year satellite data in China. Trans. Chin. Soc. Agric. Eng. 2014, 30, 140-147.

14. Wang, W.; Liu, H.; Li, Y.; Su, J. Development and management of land reclamation in China. Ocean Coast. Manag. 2014, 102, 415-425. [CrossRef]

15. Hou, X.Y.; Wu, T.; Hou, W.; Chen, Q.; Wang, Y.; Yu, L. Characteristics of coastline changes in mainland China since the early 1940s. Sci. China Earth Sci. 2016, 59, 1791-1802. [CrossRef]

16. Wu, T.; Hou, X.; Xu, X. Spatio-temporal characteristics of the mainland coastline utilization degree over the last 70 years in China. Ocean Coast. Manag. 2014, 98, 150-157. [CrossRef]

17. Ghazali, N.H.M. Coastal erosion and reclamation in Malaysia. Aquat. Ecosyst. Health Manag. 2006, 9, $237-247$. [CrossRef]

18. Ishak, N.S.; Yusup, M.; Arshad, A.F.; Abdullah, Y.A. Review on the Significance of Local Plan for Coastal Reclamation Development: The Case of Malacca, Malaysia//MATEC Web of Conferences. EDP Sci. 2016, 66,00050 .

19. Nurkin, B. Degradation of mangrove forests in South Sulawesi, Indonesia. Hydrobiologia 1994, 285, $271-276$. [CrossRef]

20. Giri, C.; Zhu, Z.; Tieszen, L.L.; Singh, A.; Gillette, S.; Kelmelis, J.A. Mangrove forest distributions and dynamics (1975-2005) of the tsunami-affected region of Asia. J. Biogeogr. 2008, 35, 519-528. [CrossRef]

21. Dat, P.T.; Yoshino, K. Monitoring Mangrove Forest using Multi-Temporal Satellite Data in the Northern Coast of Vietnam. In Proceedings of the 32nd Asian Conference on Remote Sensing, Taipei, Taiwan, 3-7 October 2011.

22. Jickells, T.D.; Andrews, J.E.; Parkes, D.J. Direct and indirect effects of estuarine reclamation on nutrient and metal fluxes in the global coastal zone. Aquat. Geochem. 2016, 22, 337-348. [CrossRef]

23. Zuhong, L.; Guizhu, C. Utilization and conservation of mangroves in South China Sea. Mar. Environ. Sci. 2007, 26, 355-359.

24. Páez-Osuna, F. The environmental impact of shrimp aquaculture: A global perspective. Environ. Pollut. 2001, 112, 229-231. [CrossRef] 
25. The World Bank. Available online: http://data.worldbank.org/indicator/NY.GDP.MKTP.CD?view=chart (accessed on 22 May 2017).

26. Al-Madany, I.M.; Abdalla, M.A.; Abdu, A.S. Coastal zone management in Bahrain: An analysis of social, economic and environmental impacts of dredging and reclamation. J. Environ. Manag. 1991, 32, 335-348. [CrossRef]

27. Zhang, C.; Xie, J.; Lou, Q.; Zhuang, D. Study on experience and countermeasures of fill up seaand build land in Guangdong. Mar. Environ. Sci. 2012, 32, 311-315.

28. Asia Development Bank. Available online: https://www.adb.org/publications/key-indicators-asia-andpacific-2011 (accessed on 22 May 2017).

29. FIPSFAO. FAO Year Book: Fishery and Aquaculture Statistics 2010; FAOL: Rome, Italy, 2012.

30. Yingliang, X. An outline of aquaculture development in Thailand. Mod. Fish. Inf. 1996, 11, 17-21.

31. Zhou, Y.; Yuan, W.; Wang, Q.; Ji, W.; Lu, Y. The current situation and development of fishery in Brunei Darussalam. Fish. Inf. Strateg. 2013, 28, 312-316.

32. Primavera, J.H. Mangroves and Brackish water Pond Culture in the Philippines. Hydrobiologia 1995, 295, 303-309. [CrossRef]

33. Son, N.T.; Chen, C.F.; Chang, N.B.; Chen, C.R.; Chang, L.Y.; Thanh, B.X. Mangrove mapping and change detection in Ca Mau Peninsula, Vietnam, using Landsat data and object-based image analysis. IEEE J. Sel. Top. Appl. Earth Obs. Remote Sens. 2015, 8, 503-510. [CrossRef]

34. Pham, T.D.; Yoshino, K. Mangrove Mapping and Change Detection Using Multi-temporal Landsat Imagery in Hai Phong city, Vietnam. In Proceedings of the International Symposium on Cartography in Internet and Ubiquitous Environments, Tokyo, Japan, 17-19 March 2015.

35. Tien, B.D.; Le, K.T.T.; Nguyen, V.C.; Le, H.D.; Revhaug, I. Tropical forest fire susceptibility mapping at the cat Ba national park area, hai phong city, vietnam, using GIS-Based kernel logistic regression. Remote Sens. 2016, 8, 347. [CrossRef]

36. Suratman, M.N.; Ahmad, S. Multi temporal Landsat TM for Monitoring Mangrove Changes in Pulau Indah, Malaysia. In Proceedings of the Business, Engineering and Industrial Applications (ISBEIA), Bandung, Indonesia, 23-26 September 2012; pp. 163-168.

37. Zu, Y.; Wei, R. Discussion on the Impact of Sea-related Engineering on Marine Ecology and Fishery Compensation Mechanism in Guangxi. China Fish. 2015, 2, 29-31.

38. Sparke, M.; Sidaway, J.D.; Bunnell, T.; Grundy-Warr, C. Triangulating the borderless world: Geographies of power in the Indonesia-Malaysia-Singapore growth triangle. Trans. Inst. Br. Geogr. 2004, 29, 485-498. [CrossRef]

(C) 2017 by the authors. Licensee MDPI, Basel, Switzerland. This article is an open access article distributed under the terms and conditions of the Creative Commons Attribution (CC BY) license (http:/ / creativecommons.org/licenses/by/4.0/). 